\title{
Effects of exogenous protease supplementation on endogenous trypsin activity and gene expression in broilers
}

\author{
L. Yuan, S.Q. Wang, Z.X. Wang, H. Zhu and K. Huang \\ College of Animal Science and Veterinary Medicine, Henan Agricultural University, \\ Zhengzhou, China \\ Corresponding author: Z.X. Wang \\ E-mail:wzxhau@aliyun.com \\ Genet. Mol. Res. 14 (4): 13633-13641 (2015) \\ Received April 9, 2015 \\ Accepted July 13, 2015 \\ Published October 28, 2015 \\ DOI http://dx.doi.org/10.4238/2015.October.28.25
}

\begin{abstract}
Two hundred and forty one-day-old male broiler chickens (Ross-308) were fed corn-soybean basal diets with $0,40,80$, or $160 \mathrm{mg} /$ $\mathrm{kg}$ of an acid protease preparation from 1 to 42 days of age, in order to investigate the effects of an exogenous enzyme on growth performance, pancreatic trypsin activity and mRNA expression. Average daily gain (ADG) was greatest in the $160-\mathrm{mg} / \mathrm{kg}$ treatment group at 1-21 days, which was significantly higher than that in the control. After 42 days, average daily feed intake (ADFI) and ADG had significantly increased in the 80and $160-\mathrm{mg} / \mathrm{kg}$ treatments $(P<0.05)$, with the $80-\mathrm{mg} / \mathrm{kg}$ treatment group having the highest ADFI and ADG values. The feed conversion ratio was not affected. Dietary acid protease at 80 and $160 \mathrm{mg} / \mathrm{kg}$ significantly decreased trypsin activity in the pancreas (relative to the control group) by 35.71 and $47.29 \%$, respectively $(P<0.05)$. After 42 days, trypsin mRNA expression in the pancreas had significantly decreased by $19.5 \%$ in the $80-\mathrm{mg} / \mathrm{kg}$ treatment group relative to the control $(P<0.05)$. After 21 and 42 days, the diet supplemented with $160 \mathrm{mg} / \mathrm{kg}$ acid protease significantly decreased pancreatic trypsin mRNA by 19.6 and $37.7 \%$, respectively, compared to the control. There were no significant differences between
\end{abstract}


the 40-mg/kg treatment group and the control. Our results suggest that the amount of acid protease in the diet significantly affects trypsin activity and mRNA expression in broilers.

Key words: Acid protease; Broiler; Endogenous trypsin; mRNA expression

\section{INTRODUCTION}

Increases in the cost of feed ingredients and society's growing expectations of reduced environmental pollution from animal agriculture have increased interest in the use of enzymes in animal diets. Research on the use of exogenous enzymes in broiler diets has been conducted for decades, ever since studies that were conducted on the hyposecretion of digestive enzymes in young broilers. Broiler feeds supplemented with a protease improve the feed conversion ratio (FCR), as well as crude protein and amino acid digestibility (Carvalho et al., 2009; Maiorka et al., 2009; Vieira et al., 2009). Increased ileal amino acid digestibility, body weight gain (BWG), and feed efficiency have been reported in birds fed corn-soybean meal diets supplemented with exogenous enzymes (Zanella et al., 1999). Increased nutrient availability due to enzyme supplementation is associated with improved digestibility or retention of energy, protein, and nutrients. Chicks that consume soybean meal diets supplemented with a protease exhibit increased BWG, nitrogen retention, and metabolizable energy, without any alteration in the FCR (Ghazi et al., 1997).

Exogenous enzymes increase the secretion of some endogenous materials from the gastrointestinal tract of broilers (Ashild and Jerry, 1989; Nitsan et al., 1991; Noy and Sklan, 1995). However, some researchers have found that supplementation with exogenous digestive enzymes can interfere with the development of digestive organs and metabolism in broilers. Therefore, it is possible that supplementation with enzymes, particularly at high levels, negatively affects broilers by interacting with the gastrointestinal tract or digestive enzyme system (Cowieson et al., 2006). Their effects depend on many factors, such as the age of the bird, type of diet, and enzyme dose (Bedford, 2000; Acamovic, 2001; Cowieson, 2005).

Trypsin is a member of the serine protease family, and is the primary protease in the alimentary canal. It plays an important role in protein digestion and the activation of other pancreatic zymogens by hydrolyzing their N-terminal short peptides (Rypniewski et al., 1994). The purpose of this study was to investigate the relationship between supplementary exogenous enzymes of microbial origin and the development of endogenous enzymes in broilers. The study focused on the effects of exogenous acid protease on the synthesis and secretory activity of trypsin.

\section{MATERIAL AND METHODS}

\section{Chickens and diets}

Two hundred and forty one-day-old male broiler chicks (Ross-308) were randomly allocated by body weight to eight treatments, with six replicate pens of 10 broilers. The broilers were housed in electrically heated cages with $24 \mathrm{~h}$ light, and provided with ad libitum food and water for 42 days. Room temperature was maintained at 33 to $35^{\circ} \mathrm{C}$ during the first week, and was gradually decreased to $24^{\circ} \mathrm{C}$ by the end of the third week. The birds were fed a corn-soybean basal diet that had been formulated by the National Research Council (Table 1). The experimental 
groups' diets were supplemented with 40,80 , or $160 \mathrm{mg} / \mathrm{kg}$ of an acid protease preparation. The acid protease (enzymatic activity 50,000 U/g) was obtained from the Shanghai Honest Biological Technology Co. Ltd. All of the diets were fed in mash form.

\begin{tabular}{|c|c|c|}
\hline & $1-21$ days & $22-42$ days Ingredients $(\%)$ \\
\hline Corn & 51.31 & 54.60 \\
\hline Soybean meal & 40.00 & 36.20 \\
\hline Soybean oil & 4.60 & 5.60 \\
\hline Dicalcium phosphate & 1.90 & 1.60 \\
\hline Limestone & 1.30 & 1.20 \\
\hline $\mathrm{NaCl}$ & 0.30 & 0.30 \\
\hline DL- Methionine & 0.20 & 0.11 \\
\hline Choline chloride & 0.20 & 0.20 \\
\hline Mineral premix ${ }^{1}$ & 0.10 & 0.10 \\
\hline Maduramicin ammonium & 0.06 & 0.06 \\
\hline Vitamin premix ${ }^{2}$ & 0.03 & 0.03 \\
\hline Total & 100.00 & 100.00 \\
\hline \multicolumn{3}{|l|}{ Nutrient levels } \\
\hline $\mathrm{ME}, \mathrm{kcal} / \mathrm{kg}$ & 2984.72 & 3092.08 \\
\hline Crude protein & 21.67 & 20.38 \\
\hline Methionine, \% & 0.55 & 0.44 \\
\hline Lysine, \% & 1.10 & 1.02 \\
\hline Threonine, \% & 0.91 & 0.84 \\
\hline Cysteine, $\%$ & 0.37 & 0.35 \\
\hline Tryptophane, \% & 0.31 & 0.28 \\
\hline Calcium, \% & 0.99 & 0.88 \\
\hline Total phosphorus, \% & 0.70 & 0.63 \\
\hline Non-phytate phosphorus, \% & 0.44 & 0.39 \\
\hline
\end{tabular}

\section{Sampling procedure}

The broilers were weighed after being starved for $12 \mathrm{~h}$ at 21 and 42 days of age, and feed consumption for each pen was recorded for the 1-21-day or 1-42-day phases. The average daily feed intake (ADFI), average daily gain (ADG), and feed to gain ratio (FGR) were recorded during the initial (1-21 days) and total (1-42 days) phases of the experiment. One chick per replicate was then randomly selected and provided with each feed for $6 \mathrm{~h}$, before being killed by cervical dislocation. The pancreas was removed and frozen immediately in liquid nitrogen, before being stored at $-70^{\circ} \mathrm{C}$.

\section{Trypsin activity assay}

Approximately $1 \mathrm{~g}$ of pancreatic tissue was placed in nine volumes of purified water to obtain a $100 \mathrm{~g}^{\cdot \mathrm{kg}^{-1}}$ homogenate. The homogenate was then centrifuged (SIGMA 2-16K, Sigma, Germany) at $4000 \mathrm{r} \cdot \mathrm{min}^{-1}$ for $15 \mathrm{~min}$, and the supernatant was collected for a trypsin activity assay. Trypsin activity was measured using a modified Schwerdt method (Stellmach, 1992). One enzyme unit was defined as the amount of enzyme in each milligram of protein that caused an increase in absorbance of 0.003 per min at $\mathrm{pH} 8.0$ and $37^{\circ} \mathrm{C}$. The protein concentrations were measured using the Coomassie Brilliant Blue method. 


\section{RNA extraction}

We extracted total RNA from 50 to $100 \mathrm{mg}$ of tissue using TRIzol reagent, based on the manufacturer instructions (Invitrogen, USA). The RNA concentration was determined by absorbance at $260 \mathrm{~nm}$ using a UV spectrophotometer(Shenzhen, China). We assessed RNA purity by measuring the OD260/OD280 ratio. The total RNA samples typically yielded an OD260/OD280 ratio of between 1.9 and 2.0 .

\section{Primer synthesis}

The primers were synthesized by the Shanghai Biological Technology Co. (China). The trypsin primer pair (P1 and $\mathrm{P} 2$ ) was designed based on the trypsin coding sequence, and the $\beta$-actin primer pair ( $P 3$ and $P 4)$ was designed based on the conserved $\beta$-actin sequence. The trypsin and $\beta$-actin cDNA primers were designed based on the GenBank sequences NM_205385 and NM_205518, respectively (Table 2).

Table 2. Primer pairs for trypsin and $\beta$-actin genes from broilers.

\begin{tabular}{llr}
\hline Primer & Sequence & Fragment length (bp) \\
\hline Trypsin & P1 5'-AGCGAGCAGACCATTAGTTC-3' & 253 \\
\multirow{3}{*}{-actin } & P2 5'-AGGAGAGTACAGGGGCATTC-3' & \\
& P3 5'-ACCGCAAATGCTTCTAAAC-3' & 93 \\
\hline
\end{tabular}

\section{Fluorescence quantitative reverse transcription polymerase chain reaction (qRT-PCR)}

We performed a real-time PCR using a SYBR ${ }^{\circledR}$ PrimeScript $^{\mathrm{TM}}$ RT-PCR Kit (Takara Biotechnology, Dalian, China) following the manufacturer instructions. Total RNA was reversetranscribed to yield cDNA using oligo-dT and reverse transcriptase at $50^{\circ} \mathrm{C}$ for $30 \mathrm{~min}$, which was followed by heat inactivation at $85^{\circ} \mathrm{C}$ for $5 \mathrm{~min}$. The cDNA samples were then mixed with $\mathrm{SYBR}^{\circledR}$ dye. We performed gene-specific and quantitative real-time PCR using a Bio-Rad iQ5 PCR machine (Bio-Rad, USA). The PCR program consisted of predenaturation at $95^{\circ} \mathrm{C}$ for 5 min, 35 cycles of denaturation at $95^{\circ} \mathrm{C}$ for $10 \mathrm{~s}$, annealing extension at $55^{\circ} \mathrm{C}$ or $56^{\circ} \mathrm{C}$ (for $\beta$-actin and amylase, respectively) for $15 \mathrm{~s}$, and at $72^{\circ} \mathrm{C}$ for $12 \mathrm{~s}$, followed by heating of the product from 60 to $95^{\circ} \mathrm{C}$ to generate the melting curve for each PCR product. One negative control was included in all of the reactions.

\section{Trypsin mRNA expression}

The quantity of trypsin mRNA in each sample was normalized by $\beta$-actin. Trypsin cDNA was quantified using relative standard curve methods, as described by Longergan et al. (2003). Because the amplification efficiency of the target and references genes differed slightly, the quantification of the gene copy number was derived from a different standard curve for the target and reference genes. The mean value of the control group samples was assigned a value of 1 , and normalized target values were expressed as a percentage of the control group. 


\section{Statistical analysis}

The experimental data were expressed as means and standard errors. The data were analyzed using an analysis of variance in SAS 8.0, and Duncan's multiple range test was used to compare treatment means. Differences were considered statistically significant at $P<0.05$.

\section{RESULTS}

\section{Performance}

The growth performance results are presented in Table 3. Supplementary acid protease had no effect on the FCR at any level ( $P>0.05)$. At 1-42 days, the ADFI and ADG had significantly increased compared to the control in the 80 and $160 \mathrm{mg} / \mathrm{kg}$ treatment groups $(P<0.05)$, with the $80 \mathrm{mg} / \mathrm{kg}$ treatment group having the highest ADG value (44.21 g/day). Dietary acid protease supplementation of $160 \mathrm{mg} / \mathrm{kg}$ significantly increased the ADG by $6.3 \%$ at $1-21$ days $(P<0.05)$, but $40 \mathrm{mg} / \mathrm{kg}$ of the protease had no significant effect on growth $(P>0.05)$.

Table 3. Effect of supplementary acid protease on body weight gain, feed intake, and feed conversion in broilers.

\begin{tabular}{|c|c|c|c|c|}
\hline \multirow[t]{2}{*}{ Item } & \multicolumn{4}{|c|}{ Supplementary amylase level (mg/kg) } \\
\hline & 0 & 40 & 80 & 160 \\
\hline \multicolumn{5}{|c|}{$1-21$ days } \\
\hline ADFI & $44.31 \pm 1.05$ & $45.31 \pm 2.82$ & $45.41 \pm 2.18$ & $46.73 \pm 1.18$ \\
\hline ADG & $28.5 \pm 0.75^{b}$ & $29.39 \pm 1.92^{\mathrm{a}, \mathrm{b}}$ & $29.46 \pm 1.55^{\mathrm{a}, \mathrm{b}}$ & $30.29 \pm 0.70^{a}$ \\
\hline FCR & $1.55 \pm 0.03$ & $1.54 \pm 0.11$ & $1.54 \pm 0.06$ & $1.54 \pm 0.08$ \\
\hline \multicolumn{5}{|c|}{$1-42$ days } \\
\hline ADFI & $81.60 \pm 1.42^{b}$ & $83.29 \pm 1.93^{\mathrm{a}, \mathrm{b}}$ & $84.49 \pm 1.80^{\mathrm{a}}$ & $84.23 \pm 2.05^{\mathrm{a}}$ \\
\hline ADG & $42.68 \pm 0.70^{b}$ & $43.77 \pm 1.05^{\mathrm{a}, \mathrm{b}}$ & $44.21 \pm 0.79^{a}$ & $43.96 \pm 1.30^{\mathrm{a}}$ \\
\hline FCR & $1.91 \pm 0.07$ & $1.90 \pm 0.14$ & $1.91 \pm 0.10$ & $1.92 \pm 0.04$ \\
\hline
\end{tabular}

Each value represents mean \pm SE of six replicates. In the same row, values with no superscript letter or the same superscript letter indicate no significant difference $(P>0.05)$; those with different superscript letters indicate a significant difference $(P<0.05)$. ADFI = average daily feed intake; $A D G=$ average daily gain; $F C R=$ feed conversion ratio.

\section{Pancreatic trypsin activity}

After 21 and 42 days, trypsin activity in the pancreas of the control group (252 and 406 $\mathrm{U} \cdot \mathrm{mg}$ protein ${ }^{-1}$, respectively) was similar to that in the $40 \mathrm{mg} / \mathrm{kg}$ dietary acid protease group (257 and $385 \mathrm{U} \cdot \mathrm{mg}_{\text {protein }}{ }^{-1}$, respectively; Figure 1). After 21 days, dietary acid protease at the $160 \mathrm{mg} /$ kg level significantly decreased trypsin activity by $26.2 \%(P<0.05)$ in comparison to the control. After 42 days, dietary acid protease at the 80 and $160 \mathrm{mg} / \mathrm{kg}$ levels significantly decreased trypsin activity by 35.71 and $47.29 \%$, respectively, compared to the control $(P<0.05)$.

\section{Pancreatic trypsin mRNA expression}

The amount of acid protease in the diet significantly affected trypsin mRNA expression in the broilers (Figure 2). After 42 days, trypsin mRNA expression in the pancreas had significantly decreased by $19.5 \%$ in the $80 \mathrm{mg} / \mathrm{kg}$ acid protease treatment group relative to the control $(P<0.05)$. After 21 and 42 days, the diet supplemented with $160 \mathrm{mg} / \mathrm{kg}$ acid protease significantly decreased 
pancreatic trypsin mRNA by 19.6 and $37.7 \%$, respectively, compared to the control. However, there was no significant difference between the $40 \mathrm{mg} / \mathrm{kg}$ treatment group and the control.

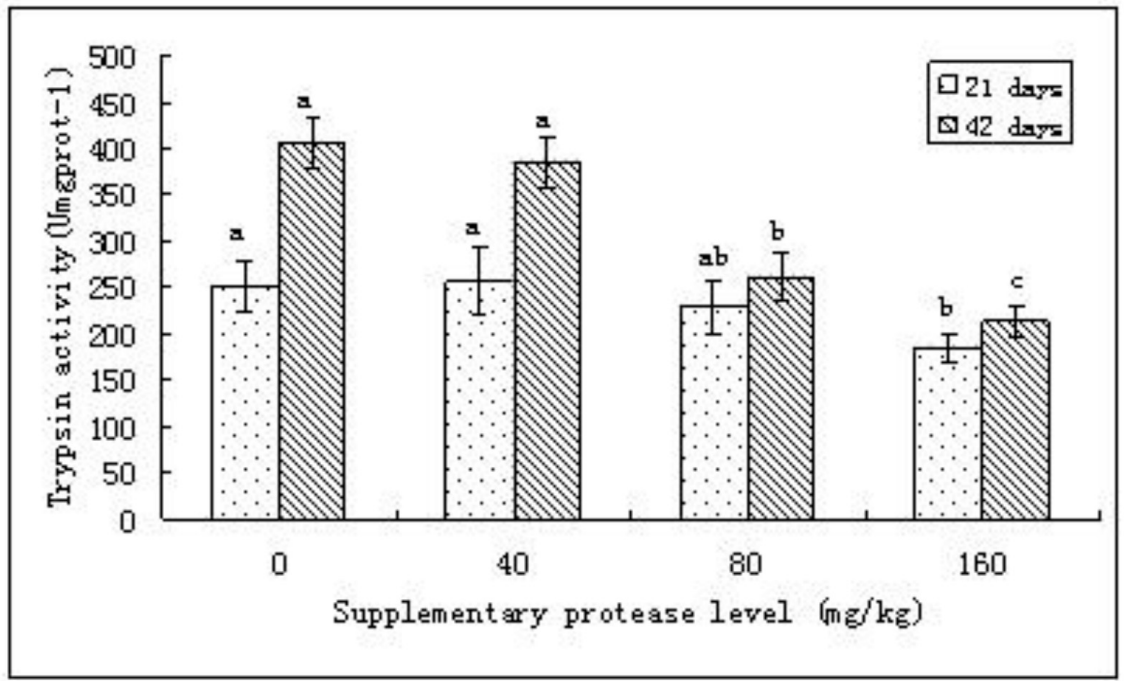

Figure 1. Pancreatic trypsin activity in broilers fed diets supplemented with different acid protease levels (number of samples $=6$ ).

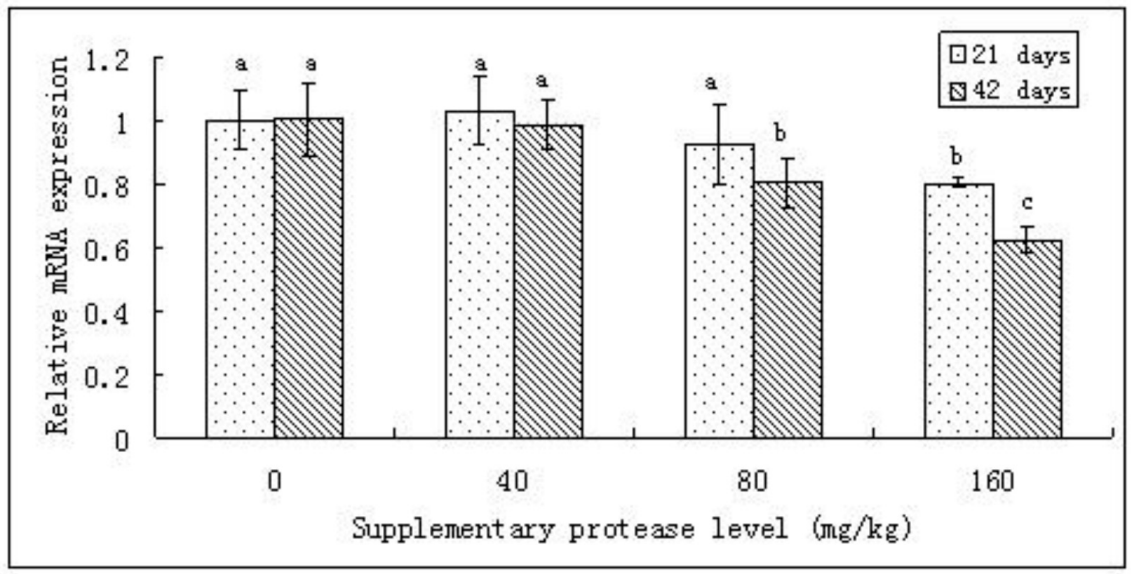

Figure 2. Pancreatic trypsin mRNA expression in broilers fed diets supplemented with different acid protease levels (number of samples $=6$ ).

\section{DISCUSSION}

Amino acids are costly nutrients that (with the exception of their synthetic forms) originate from dietary proteins. There have been several studies conducted on the effects of exogenous proteases in poultry diets on performance. Ghazi et al. (2003) reported that the use of one monocomponent protease resulted in increased ADG and AFDI, but the FCR was either negatively 
affected or not affected at all, depending on the protease concentration used. Gracia et al. (2003) reported a $9.4 \%$ improvement in BWG and a $4.2 \%$ increase in the FCR in seven-day-old broilers fed corn-soybean meal diets supplemented with a single exogenous $\alpha$-amylase. However, Mahagna et al. (1995) found no beneficial effect of 250 or $1000 \mu \mathrm{g} / \mathrm{kg}$ amylase or protease-preparation supplementations on feed intake or growth rate from 1 to 14 days with a sorghum-soybean diet. In the present study, the addition of $80 \mathrm{mg} / \mathrm{kg}$ of acid protease to a corn-soybean basal diet improved the ADFI and ADG at $1-42$ days by 3.5 and $3.6 \%$, respectively. Dietary acid protease at the 160 $\mathrm{mg} / \mathrm{kg}$ level increased the ADFI and ADG at 1-21 days (by 5.5 and $6.3 \%$, respectively) and at $1-42$ days (by 3.2 and $3.0 \%$, respectively) compared to the control group. There was no effect on the FCR at any level of acid protease supplementation. Protein degradation is largely mediated by gastric and pancreatic secretions. Lemme et al. (2004) and Parsons et al. (1997) stated that protein digestibility depends upon the ingredients used in broiler feeds; therefore, undigested or incompletely digested protein represents an important opportunity for using exogenous proteases in broiler feeds.

The effects of exogenous enzymes in poultry diets on endogenous enzyme activity are frequently inconsistent. Ritz et al. (1995) reported that pancreatic enzyme activity did not significantly change after oral digestive enzyme administration, and suggested that differences in the physical structures between endogenous animal enzymes and those of bacterial or plant origin may prevent feedback inhibition of pancreatic enzyme production. However, Mahagna et al. (1995) found that intestinal protease activity decreased when chicks were fed diets supplemented with exogenous amylase and protease. Jiang et al. (2008) found that pancreatic amylase activity decreased from 9 to $33 \%$ with increasing levels of exogenous amylase (250 to $2250 \mathrm{mg} / \mathrm{kg}$ ), which may indicate a negative pancreatic enzyme production response. Differences in the types and amounts of enzyme used, as well as in experimental design (particularly the nutrients used in negative controls), can partly explain the conflicting and highly variable results that have been reported. In the present study, we found a significant decrease in pancreatic trypsin activity with exogenous acid protease supplementation. Our results indicate that there may be beneficial effects of protease supplementation on the secretion of trypsin.

Trypsin is mainly synthesized by pancreatic tissues; in our study, a decrease in pancreatic trypsin activity was associated with a change in trypsin mRNA expression, and the amount of acid protease in the diet significantly affected trypsin mRNA expression. This suggests that the presence of exogenous acid protease in the intestine influences trypsin at the transcriptional level. Protease activity is regulated by three different mechanisms: zymogen synthesis, zymogen activation, and protease inactivation by inhibitors (Neurath, 1984). Trypsin activity is regulated by all of these mechanisms. Furthermore, trypsinogen synthesis is regulated at three levels: transcription, translation, and post-translation. Whether regulation in broilers is caused directly or indirectly by exogenous protease, and whether it responds at the transcriptional, translational, or secretory level remains unclear, because of the difficulty in distinguishing between exogenous and endogenous proteases in the intestine. Xu et al. (2006) reported that pancreatic amylase activity decreased with a low-starch diet. Lhoste et al. (1994) found that trypsin activity and mRNA expression increased in rats fed a diet containing $500 \mathrm{~g}^{\cdot \mathrm{kg}^{-1}}$ casein. Therefore, decreases in trypsin expression may be caused by protein breakdown in the intestine by exogenous acid protease, which may result in a decreased dietary stimulus to the gastrointestinal tract neural system and a downregulation of trypsin expression. Rothman et al. (2002) pointed out that a large proportion of the digestive enzymes secreted by the pancreas are absorbed into the blood and recycled in the enteropancreatic 
circulation, which is similar to the enterohepatic circulation. If so, an increased presence of dietary acid protease would elevate levels of circulating proteases, and correspondingly increase protease accumulation in the pancreas. If this is the case, the increasing involvement of dietary proteases in the enteropancreatic circulation may negatively affect the pancreatic production of trypsin mRNA or protein. The pancreas is responsible for both the synthesis and secretion of digestive enzymes. If the synthetic rate is the same as the secretory rate, and if trypsin mRNA expression decreases under the mitigation of a neural stimulus or the endogenous interference of the enteropancreatic circulation, or both, trypsin secretion would decrease. This may explain the decrease in pancreatic trypsin activity and mRNA expression when a large amount of dietary protease was added to broiler diets in this study.

Supplementary dietary acid protease at the $80 \mathrm{mg} / \mathrm{kg}$ level resulted in the highest broiler ADG in our experiment. High levels of dietary acid protease not only increase feed cost but also decrease levels of endogenous trypsin, which negatively affects growth performance. Exogenous enzyme supplementation also negatively affected pancreatic enzyme mRNA levels, suggesting that caution should be exercised when supplementing poultry diets with high levels of exogenous pancreatic enzyme analogs.

\section{Conflicts of interest}

The authors declare no conflict of interest.

\section{REFERENCES}

Acamovic T (2001). Commercial application of enzyme technology for poultry production. World's Poult. Sci. J. 57: $225-243$. Ashild K and Jerry LS (1989). Influence of age on lipase, amylase, and protease activities in pancreatic tissue and intestinal contents of young turkeys. Poult. Sci. 68: 1561-1568.

Bedford MR (2000). Exogenous enzymes in monogastric nutrition-their current value and future benefits. Anim. Feed Sci. Technol. 86: 1-13.

Carvalho JCC, Bertechini AG, Rios RL, Mesquita FR, et al. (2009). Use of a protease to enhance the utilization of corn amino acids by broilers. Poult. Sci. 88: 69-70.

Cowieson AJ (2005). Factors that affect the nutritive value of maize for broilers. Anim. Feed Sci. Technol. 119: $293-305$.

Cowieson AJ, Acamovic T and Berford MR (2006). Using the precision-feeding bioassay to determine the efficacy of exogenous enzymes - a new perspective. Anim. Feed Sci. Technol. 129: 149-158.

Ghazi S, Rooke JA, Galbraith H and Bedford MR (1997). Effect of adding protease and alpha-galactosidase enzyme to soybean meal on nitrogen retention and true metabolisable energy in broilers. Br. Poult. Sci. 38: 28.

Ghazi S, Rooke JA and Galbraith H (2003). Improvement of the nutritive value of soybean meal by protease and a-galactosidase treatment in broiler cockerels and broiler chicks. Br. Poult. Sci. 44: 410-418.

Gracia MI, Aranibar MJ, Lazaro R, Medel P, et al. (2003). Alpha-amylase supplementation of broiler diets based on corn. Poult. Sci. 82: 436-442.

Jiang ZY, Zhou YM, Lu FZ, Han ZY, et al. (2008). Effects of different levels of supplementary alpha-amylase on digestive enzyme activities and pancreatic amylase mRNA expression of young broilers. Asian-Aust. J. Anim. Sci. 21: 97-102.

Lemme A, Ravindran V and Bryden WL (2004). Ileal digestibility of amino acids in feed ingredients for broilers. World's Poult. Sci. 60: 423-437.

Lhoste EF, Fiszlewicz M and Gueugneau AM (1994). Adaptation of exocrine pancreas to dietary proteins: effect of the nature of protein and rat strain on enzyme induction and messenger mRNA levels. J. Nutr. Biochem. 5: 84-94.

Lonergan P, Rizos A, Gutierrez AP, Moriera PM, et al. (2003). Temperal divergence in pattern of messenger RNA expression in bovine embryos cultured from the zyogte to blastocyst stage in vitro or in vivo. Biol. Reprod. 69: 1424-1431.

Mahagna M, Nir I, Larbier M and Nitsan Z (1995). Effect of age and exogenous amylase and protease on development of the digestive tract, pancreatic enzyme activities and digestibility of nutrients in young meat-type chicks. Reprod. Nutr. Dev. 35: 201-212. 
Maiorka A, Favero A, Meurer RFP, Moraes MTT, et al. (2009). Broiler chicken performance and ileal digestibility is improved by a protease used in corn/soybean meal/meat bone meal diet. Poult. Sci. 88: 33.

Neurath H (1984). Evolution of proteolytic enzymes. Science 224: 350-357.

Nitsan Z, Avraham G, Zoref Z and Nir I (1991). Growth and development of the digestive organs and some enzymes in broiler chicks after hatching. Br. Poult. Sci. 32: 515-523.

Noy $Y$ and Sklan D (1995). Digestion and absorption in the young chick. Poult. Sci. 74: 366-373.

Parsons CM, Castanon F and Han Y (1997). Protein and amino acid quality of meat and bone meal. Poult. Sci. 76: 361-368.

Ritz CW, Halet RM, Self BB and Denbow DM (1995). Endogenous amylase levels and response to supplementation feed enzymes in male turkeys from hatch to eight weeks of age. Poult. Sci. 74: 1317-1322.

Rothman S, Liebow C and Isenman L (2002). Conservation of digestive enzymes. Physiol. Rev. 82: 1-18.

Rypniewski W, Perrakis A and Vorgias CE (1994). Evolutionary divergence and conservation of trypsin. Protein Eng. 7: 57-64.

Stellmach B (1992). Bestimmungsmethoden enzyme (in Chinese, interpreted by Qian JY). Chinese Light Industry Press, Beijing, China, 122-123.

Vieira SL, Freitas DM, Pen $\square$ a JEM, Barros R, et al. (2009). Performance and amino acid utilization by broilers supplemented with a novel exogenous protease. Poult. Sci. 88 (Suppl 1): 37.

Xu M, Yao JH, Wang YH and Wang FN (2006). Influence of rumen escape starch on $\alpha$-amylase activity in pancreatic tissue and small intestinal digesta of lambs. Asian-Aust. J. Anim. Sci. 19: 1749-1754.

Zanella I, Sakomura NK, Silversides FG, Fiqueirdo A, et al. (1999). Effect of enzyme supplementation of broiler diets based on corn and soybeans. Poult. Sci. 78: 561-568. 